\title{
FRAX Tool in Brazil: an integrative literature review following validation
}

\section{Abstract}

The present article is an integrative review the objective of which was to assess research carried out with the FRAX tool in Brazil following its validation, and describe the conclusions drawn. Two databases were used to select the articles (the Capes Portal and the Virtual Health Library), and the sample of this review was the only four articles published in Brazil relating to the FRAX tool following its validation in May 2013. After analyzing the articles, the results demonstrated that despite some limitations the FRAX Tool can be used to reduce the prevalence of fractures due to its simplicity of use, with an emphasis on prediction and orientation, allowing early and safe therapeutic decision-making.

\section{Keywords: FRAX.}

Osteoporotic Fractures.

Diagnosis. Mass Screening. Diagnostic Techniques and Procedures. Brazil.

Universidade Católica de Brasília, Escola de Saúde e Medicina, Programa de Pós-graduação Stricto Sensu em Gerontologia. Brasília, DF, Brasil. 


\section{INTRODUCTION}

The role of the gynecologist can be described as that of a doctor who treats only women, carrying out their professional practice in a certain social space by making use of the instruments of the culture of their society and producing knowledge and representations with specific purposes, aiming at the integrated care of women in a clinical setting, especially when the patient is elderly ${ }^{1}$.

The role of the gynecologist, in the social and technical space of his or her surgery, is growing in complexity, in that it must interconnect the human aspects explicit in patient care, considering the patient as a unique individual in terms of their particularities and frailties, simultaneously with the nuances of the interpersonal relationship ${ }^{1}$.

It is therefore understood that the sphere of action expected of the gynecologist today, in addition to listening to these patients and the performance of the inherent activities of the specialty itself, such as specific physical examinations and the requesting the mandatory complementary exams required by medical protocols, more complete complementary exams for the screening and prevention of diseases for the reduction of morbidities. Often, the gynecologist is the only doctor the woman seeks on a regular basis. This care is based on the understanding that we must reduce the missed opportunities to carry out a complete diagnosis of such women, especially when they are elderly, when several comorbidities appear'.

Such diseases include osteoporosis, considered one of the most common and serious health problems of the elderly female population in developed countries. This disease is characterized by low bone density and the degeneration of the bone microarchitecture, which leads to an increase in bone fragility and the increased risk of fracture. Bone mass increases in childhood and adolescence, peaks in the third or fourth decade of life, and declines thereafter. The groups at greatest risk for osteoporosis are postmenopausal, white, Asian, lean, small women with a family history of the disease ${ }^{2-4}$.

According to recent estimates, it is estimated that osteoporosis affects 200 million women worldwide and that there are now 44 million people in the USA with osteoporosis or osteopenia. The predictions for 2020 are that there will be more than 61 million individuals with osteoporosis or low bone mineral density (BMD) in the USA alone ${ }^{2,4}$.

According to the National Osteoporosis Foundation, an osteoporotic fracture occurs every three seconds and an osteoporotic vertebral fracture every twenty-two seconds.

Osteoporotic fractures impose serious physical, psychosocial and financial barriers, both for the patient and for society ${ }^{5}$.

The introduction of the FRAX (Fracture Risk Assessment Tool) facilitated the evaluation of the risk of bone fractures. FRAX was developed by the World Health Organization Collaborating Center for Metabolic Bone Diseases of the University of Sheffield, England, in partnership with the World Health Organization (WHO) and was launched in 2008. It is based on the individual analysis of each patient, correlating risk factors with the bone mineral density of the femur as measured by bone densitometry. The algorithm calculates the probability of bone fractures from easily obtained clinical factors and the result is the likelihood of a fracture of the femur or other bones in the subsequent ten years. The probability is calculated from data such as age, gender, body mass index (BMI), and risk factors such as history of fractures due to bone fragility, family history of femoral fracture, smoking, prolonged use of steroids, rheumatoid arthritis, other causes of secondary osteoporosis and high alcohol consumption ${ }^{6,7}$.

Approximately 21\% of women aged 50-84 years in the biggest countries in Europe (Germany, France, Italy and the United Kingdom) have osteoporosis, which means more than 12 million women in these countries alone ${ }^{8}$.

Following its creation, the FRAX tool has been calibrated for different countries based on mortality rates and bone fractures specific to each country. The model is now available in 28 languages (Arabic, English, Traditional and Simplified Chinese, Danish, Finnish, French, German, Japanese, Polish, Russian, Spanish, Portuguese, Swedish, Turkish, Bengali, Czech, Dutch, Greek, Icelandic, Indonesian, Italian, 
Korean, Lithuanian, Norwegian, Romanian, Slovak, Thai) and has already been validated for more than 30 countries $^{9,10}$.

It is available as an application for IOS and Android and is both appreciated and criticized for its simplicity. It is not applicable for patients where treatment is clearly indicated and in very elderly patients with various bone fractures due to frailty?

FRAX is currently the most widely used tool in the selection of individuals for the treatment of osteoporosis. For this reason, in July 2017, the Brazilian Federation of Gynecology (FEBRASGO) recommended the use of the tool in gynecological consultations, aiming to improve the care provided to women ${ }^{1}$.

The justification for the use of the tool by gynecologists is the knowledge that the main risk factors associated with loss of bone mass are advanced age, female gender and the postmenopausal period. Thus, evaluative studies on the importance of the use of the tool in Brazil are required.

Given this context, the present study aims to investigate the use of the FRAX tool in Brazil following its validation, synthesize and interpret the results of these studies and discuss the main recommendations and limitations of the tool.

\section{METHODS}

This is an integrative review based on a retrospective and documentary study, carried out through a survey of the scientific productions published between 2013 and 2017 and located in the Library of the Capes Portal (Coordination for the Improvement of Higher Level Personnel), which includes numerous databases, and the Virtual Health Library, which includes the Medline and Lilacs databases.

An integrative review involves the analysis of studies, providing scientific basis for decision making, improving the results obtained in clinical practice, with the perspective of increasing knowledge in a specific subject, as well as helping to fill gaps identified in previous studies. It also allows the use of several studies to highlight a line of research ${ }^{11}$.
The integrative review followed the following steps: definition of the theme and guiding question; establishment of inclusion and exclusion criteria; definition of the information to be extracted from the studies; evaluation of studies; interpretation of the main results and the preparation of the document that includes all these phases ${ }^{12}$.

After defining the topic, the following question was asked: what knowledge was produced in Brazil by articles on the FRAX Tool following its validation in the country in 2013?

The only guiding axis used to obtain the publications in the study was the descriptor registered in $\mathrm{MeSH}$ (Medical Subject Headings), as nothing related to the FRAX tool was found in the Descriptors in Health Sciences (Desc/Virtual Health Library). The descriptors "FRAX tool" and "Brazil" and "ten-year fracture probability" in English and Portuguese were used, interconnected by the Boolean operator AND.

The following inclusion criteria were adopted for data collection: surveys available online, referring to research carried out in Brazil, in the English or Portuguese languages, with free access to the entire publication, published in the last five years, indexed in periodicals available in the Capes Portal Library (Coordination for Improvement of Higher Level Personnel) and the Virtual Health Library (VHL). The following databases were used in this study: Scientific Electronic Library Online (Scielo), National Library of Medicine (PubMed), Latin American and Caribbean Literature in Health Sciences (Lilacs), Medical Literature Analysis and Retrieval System Online (Medline).

The following were excluded: medical guides, reviews, comments, technical and scientific reports, dissertations, ministerial and governmental documents, and other documents that did not follow the IMRDC format (introduction, method, result, discussion and conclusion) of a scientific article. Repeated articles were also excluded as well as those where the central theme was not the FRAX tool.

The search process of manuscripts in the referred databases resulted in 44 articles referring to the descriptor "FRAX tool and Brazil". 
After establishing the inclusion criteria and the reading of the titles and abstracts seven texts related to the descriptor described above were selected.

The detailed exclusion criteria were then applied. A careful analysis and an integral reading of the articles was also carried out, and four articles were chosen to form the basis of the analysis of this study.

The following criteria were used to collect the data of the articles that were included in the integrative review: identification of the original article, methodological characteristics of the study, evaluation of methodological rigor and application in FRAX tool article.

For the analysis and subsequent synthesis of the articles that met the inclusion criteria, a synoptic framework specially designed for this purpose was used, which included the following aspects: name of the study; authors name; title of the periodical; language; year; institution; research design; goals; results and recommendations.

In order to have access to the full text of the article, the available link was selected directly in the VHL database or in Capes. However, the content of the abstract did not always correspond to the description contained in the article. For this reason, for the construction of this study, we opted to read all the publications analyzed in full.

For the mapping of the set of scientific productions, the following variables were identified:

- Area of knowledge of the journal or of professional activity: according to the information at the beginning of the article, referring to the authors or to the title of the journal;

- Methodological or study approach: the studies were considered quantitative when they involved statistical inferences with a mathematical description; qualitative, when they evaluated the relationships and human activities represented in collective or individual consciences; and quantitative, when both approaches were used in a complementary manner.

\section{RESULTS AND DISCUSSION}

In the present integrative review, we analyzed four articles that met the inclusion criteria. An overview of the evaluated articles is shown below.

Chart 1. Description of articles included in integrative review.

\begin{tabular}{|l|l|l|l|l|l|}
\hline & Study title & $\begin{array}{l}\text { Title of } \\
\text { Periodical }\end{array}$ & Authors & $\begin{array}{l}\text { Language/ } \\
\text { Year }\end{array}$ & Institution \\
\hline A1 & $\begin{array}{l}\text { Correlation between osteoporotic fracture } \\
\text { risk in Brazilian postmenopausal women } \\
\text { calculated using the FRAX with and without } \\
\text { the inclusion of bone densitometry data }\end{array}$ & $\begin{array}{l}\text { Arch } \\
\text { Osteoporos }\end{array}$ & $\begin{array}{l}\text { Bastos- } \\
\text { Silva,Y, et } \\
\text { al. }\end{array}$ & English/2016 & $\begin{array}{l}\text { Universidade de } \\
\text { Campinas }\end{array}$ \\
\hline A2 & $\begin{array}{l}\text { Low health related quality of life associated } \\
\text { with fractures in obese postmenopausal } \\
\text { women in Santa Maria, Brazil }\end{array}$ & $\begin{array}{l}\text { Bone } \\
\text { Reports }\end{array}$ & $\begin{array}{l}\text { Copês, } \\
\text { R.M. et al. }\end{array}$ & English/2017 & $\begin{array}{l}\text { Universidade } \\
\text { Federal de Santa } \\
\text { Maria }\end{array}$ \\
\hline A3 & $\begin{array}{l}\text { Low self-awareness of osteoporosis and } \\
\text { fracture risk among postmenopausal women }\end{array}$ & $\begin{array}{l}\text { Arch } \\
\text { Osteoporos }\end{array}$ & $\begin{array}{l}\text { Langer, F. } \\
\text { W.et al. }\end{array}$ & English/2016 & $\begin{array}{l}\text { Universidade } \\
\text { Federal de Santa } \\
\text { Maria }\end{array}$ \\
\hline A4 & $\begin{array}{l}\text { Incidence of hip fracture in Brazil and the } \\
\text { development of a FRAX model. }\end{array}$ & $\begin{array}{l}\text { Arch } \\
\text { Osteoporos }\end{array}$ & $\begin{array}{l}\text { Zerbini, C. } \\
\text { A. F. et al. }\end{array}$ & English/2015 & $\begin{array}{l}\text { Centro Paulista } \\
\text { de Investigação } \\
\text { clínica e outros }\end{array}$ \\
\hline
\end{tabular}


The four articles included in the integrative review were written by physicians. One was developed in a research center and three were epidemiological studies carried out by universities. Three surveys were performed in single institutions while one had a multicentric approach.
All the articles were published in international osteoporosis medical journals, and all were published in or after 2015 and in English.

Chart 2. Designs and aims of articles.

\begin{tabular}{|c|c|c|c|c|}
\hline & Study design & Aims & Results & Recommendations \\
\hline A1 & $\begin{array}{l}\text { Cohort study, } \\
\text { exploratory and } \\
\text { comparative design. }\end{array}$ & $\begin{array}{l}\text { To assess the degree } \\
\text { of agreement between } \\
\text { the risk of fractures in } \\
\text { the next ten years in } \\
\text { menopausal women } \\
\text { calculated by the } \\
\text { FRAX tool with and } \\
\text { without inclusion of } \\
\text { bone mineral density }\end{array}$ & $\begin{array}{l}\text { FRAX represents a good } \\
\text { alternative for predicting } \\
\text { fracture risk, identifying } \\
\text { patients that should be } \\
\text { treated even without } \\
\text { knowledge of bone mineral } \\
\text { density, avoiding the } \\
\text { need to submit patients } \\
\text { to densitometry, which is } \\
\text { unavailable in several regions }\end{array}$ & $\begin{array}{l}\text { It is necessary to define } \\
\text { the threshold for initiating } \\
\text { pharmacological treatment } \\
\text { based on the FRAX risk } \\
\text { rate for use in the Brazilian } \\
\text { population. }\end{array}$ \\
\hline A2 & $\begin{array}{l}\text { Cohort study, } \\
\text { exploratory and } \\
\text { comparative design. }\end{array}$ & $\begin{array}{l}\text { To explore the effect } \\
\text { of both obesity and } \\
\text { fractures on self- } \\
\text { reported quality of life }\end{array}$ & $\begin{array}{l}\text { Lower rates of self-reported } \\
\text { quality of life were found in } \\
\text { obese women with fractures } \\
\text { in comparison with obese } \\
\text { women without fractures } \\
\text { and non-obese women with } \\
\text { fractures }\end{array}$ & $\begin{array}{l}\text { The FRAX tool should } \\
\text { be modified as it does not } \\
\text { effectively measure risk in } \\
\text { obese people, underestimating } \\
\text { the probability of fractures } \\
\text { and leaving them untreated. } \\
\text { In addition, there is a need for } \\
\text { studies to evaluate the efficacy } \\
\text { of the anti-fracture effect of } \\
\text { different medications in obese } \\
\text { patients. }\end{array}$ \\
\hline A3 & $\begin{array}{l}\text { Cohort study, } \\
\text { exploratory and } \\
\text { comparative design. }\end{array}$ & $\begin{array}{l}\text { To evaluate the } \\
\text { concordance between } \\
\text { self-perception of } \\
\text { osteoporosis and } \\
\text { risk of fracture with } \\
\text { the risk of fracture } \\
\text { in the next ten years } \\
\text { calculated by the } \\
\text { FRAX Tool }\end{array}$ & $\begin{array}{l}\text { There is no agreement } \\
\text { between the self-perception } \\
\text { of fracture risk and the risk } \\
\text { calculated by FRAX. A } \\
\text { total of } 79.3 \% \text { of the women } \\
\text { identified as having a high } \\
\text { risk of fractures by FRAX } \\
\text { perceived themselves as } \\
\text { having low risk }\end{array}$ & $\begin{array}{l}\text { Need for educational } \\
\text { measures on osteoporosis in } \\
\text { postmenopausal patients }\end{array}$ \\
\hline A4 & $\begin{array}{l}\text { Cohort study, } \\
\text { exploratory design. }\end{array}$ & $\begin{array}{l}\text { To calculate the } \\
\text { mean age and gender } \\
\text { referring to rates of } \\
\text { femur fractures in } \\
\text { Brazil for the creation } \\
\text { of the Brazilian } \\
\text { FRAX Tool and to } \\
\text { be able to perform } \\
\text { interventions. }\end{array}$ & $\begin{array}{l}\text { The incidence of fractures } \\
\text { increases with age, with } \\
\text { a preponderance in men } \\
\text { when young and in women } \\
\text { when over } 50 \text { years. The } \\
\text { probability of bone fracture } \\
\text { was higher in patients with } \\
\text { clinical risk factors such } \\
\text { as parents with femoral } \\
\text { fractures, lower bone density, } \\
\text { low BMI, women with a } \\
\text { history of previous bone } \\
\text { fracture and advanced age. }\end{array}$ & $\begin{array}{l}\text { Interventions should be } \\
\text { applied in elderly women with } \\
\text { a history of previous fractures. } \\
\text { The FRAX tool is the first } \\
\text { model for the prediction of } \\
\text { fracture risk specific to Brazil } \\
\text { based on the original method } \\
\text { and has been validated by } \\
\text { several independent cohort } \\
\text { studies. } \\
\text { Despite some limitations, it } \\
\text { is effective for use in clinical } \\
\text { practice. }\end{array}$ \\
\hline
\end{tabular}


In terms of the research design of the evaluated articles, four were cross-sectional population epidemiological studies, while one was the description of the validation of the FRAX Brazil Tool with retrospective application.

Regarding the purpose of this review, that is, to investigate the use of FRAX in Brazil after its validation in 2013, four articles were found.

In relation to the second specific objective to synthesize and identify the results of these studies, there seems to be agreement that the FRAX Tool is an important and simple method of screening for the risk of fractures in the next ten years at the outpatient level.

In terms of the objective of discussing its main indications and limitations, a consensus was found in recommending the use of this tool in clinical practice for elderly patients, especially for postmenopausal and elderly women, the highest risk group.

One article described the use of the FRAX tool in obese women and concluded that high body mass index could mask the risk of fractures, underestimating this outcome ${ }^{13}$.

One study demonstrates the lack of knowledge about the real condition of bone quality and the risk of fractures among women, concluding that there is a need for educational measures on osteoporosis in postmenopausal patients ${ }^{14}$.

However, a 2012 multi-center study conducted in a partnership between the Universities of Santa Maria in Brazil, the University of Cambridge in England and four study centers in the USA, with 6,049 women of whom $18.5 \%$ were obese, concluded that the FRAX tool is valid for the prevention of fractures in obese postmenopausal women, particularly when using bone density results ${ }^{15}$.

The lack of information about the disease shows the difficulty in medical practice of establishing a better form of control and treatment. In this item the FRAX tool is useful for the individual screening of the risk of fractures and the possibility of introducing personal modifications in the quality of life of these patients ${ }^{16}$.

Changes in the personal sphere can promote greater health and functionality for the elderly, as well as reduce mortality and the use of the health system with a consequent reduction of $\operatorname{costs}^{17}$. This reinforces the need for educational and preventive measures; firstly in an attempt to reduce the number of patients with osteoporosis, and secondly to intervene as early as possible in favor of patients with osteoporosis, so that they remain physically active and can reduce the occurrence of fractures ${ }^{16}$.

The study that compared the risk of fractures in the following ten years with and without the use of bone mineral density, which is only accessible through the bone densitometry test, found similar results for the two approaches. This finding is important as there are regions of Brazil where it is impossible to perform bone densitometry ${ }^{18}$, and shows the tool could represent a strategy for reducing the prevalence of fractures through outpatient use due to its simplicity of application, allowing early and safe therapeutic decision making.

The limitations of FRAX are described in the updates of the tool in 2016 and include: the use of the tool in people born in one country, but descended from immigrants from another nation, for whom the tool used should be that of the country of origin of the parents; the impossibility of using the tool as the only screening strategy for treatment, as it does not allow the inclusion of risks such as previous fracture of the femur, the dose of the glucocorticoid used, the level of smoking, the result of spine densitometry, as well as the previous history of falls, reflecting a failure to capture important data. It is known that the high risk of falling in a patient alone increases the risk of fracture by $30 \%$.

This integrative review consists of a broad literature review, contributing to discussions about research results, as well as considerations about future studies. The purpose of this research method is to obtain knowledge of a particular phenomenon, in this case the use of the FRAX tool in Brazil, 
based on previous studies, and should include a satisfactory level of information, after gathering and synthesizing the evidence available in the literature, allowing the reader to evaluate the adequacy of the procedures used in the preparation of the review, aspects related to the subject addressed and the details of the included studies. Limitations include the inclusion of several studies with different research designs, which can hamper the final analysis ${ }^{12}$.

A limitation of the present study was the small number of articles found, even though several databases were searched (those belonging to the Capes Portal and the VHL) as the objective of the research were studies on the FRAX tool in Brazil only and after 2013.

\section{REFERENCES}

1. Federação Brasileira das Associações de Ginecologia e Obstetrícia [Internet]. Porque o Ginecologista deve se envolver no rastreamento, prevenção e tratamento da Osteoporose? Rio de Janeiro: FEBRASGO; 2017 [acesso em 20 jul. 2017]. Disponível em: https:// www.febrasgo.org.br/noticias/item/130-porque-oginecologista-deve-se-envolver-no-rastreamentoprevencao-e-tratamento-da-osteoporose

2. Borges JLC, Maia JL, Silva RF, Lewiecki EM. Diagnóstico de fraturas vertebrais: oportunidades perdidas. Rev Bras Reumatol [Internet]. 2015 [acesso em 12 fev. 2017];55(5):464-7. Disponível em: http://www.scielo.br/pdf/rbr/v55n5/0482-5004rbr-55-05-0464.pdf

3. Marinho BCG, Guerra JP, Drummond JB, Silva BC, Soares MMS. The burden of osteoporosis in Brazil. Arq Bras Endocrinol Metab [Internet]. 2014 [acesso em 12 dez. 2017];58(5):434-43. Disponível em: http://www.scielo.br/scielo.php?script $=$ sci_ arttext\&pid=S0004-27302014000500434\&lng=en\&n $\mathrm{rm}=$ iso\& $\ln \mathrm{ln}=\mathrm{en}$

4. Baccaro LF, Machado VSS, Costa-Paiva L, Sousa MH, Osis MJ, Pinto-Neto AM. Factors associated with fragility fractures in women over 50 years of age: a population-based household survey. Rev Bras Ginecol Obstet [Internet]. 2013 [acesso em 12 dez. 2017];35(11):497-502. Disponível em: http://www. scielo.br/scielo.php?script $=$ sci_arttext\&pid $=$ S010072032013001100004\&lng=en

\section{CONCLUSION}

It was found that in general all the authors demonstrated that the tool, despite some limitations, is an important and simple method of screening the risk of fractures at an outpatient level, and is one of the strategies which can be used to reduce the prevalence of fractures due to its simplicity of application, allowing early and safe therapeutic decision-making.

The earlier we identify patients with a medium and high risk of fracture, the earlier we can begin to treat them and further raise awareness, allowing them to modify living habits that decrease their health and interfere with their bone mass, reducing their morbidity and improving their quality of life.

5. Bringel AL, Andrade KFS, Silva Junior ND, Santos GG. Suplementação nutricional de cálcio e vitamina D para a saúde óssea e prevenção de fraturas osteoporóticas. Rev Bras Ciênc Saúde. 2015;18(4):353-8.

6. Bastos-Silva Y, Aguiar LB, Pinto-Neto AM, Baccaro LF, Costa-Paiva L. Correlation between osteoporotic fracture risk in Brazilian postmenopausal women calculated using the FRAX with and without the inclusion of bone densitometry data. Arch Osteoporos. 2016;11(1):1-7.

7. FRAX Tool. Instrumento de avaliação do risco de fratura [Internet]. Sheffield: Center for Metabolic Bone Diseases; 2008 [acesso em 09 ago. 2016]. Disponível em: https://www.shef.ac.uk/FRAX/tool. jsp?lang $=\mathrm{pt}$

8. Kanis JA, Burlet N, Cooper C, Delmas PD, Reginster JY, Borgstrom F, et al. European guidance for the diagnosis and management of osteoporosis in postmenopausal women. Osteoporos Int. 2008;19(4):399-428.

9. McCloskey E, Harvey N, Johansson H, Kanis JA. FRAX updates 2016. Curr Opin Rheumatol. 2016;28(4):433-41.

10. Zerbini CAF, Szejnfeld VL, Abergaria BH, McCloskey EV, Johansson H, Kanis JA. Incidence of hip fracture in Brazil and the development of a FRAX model. Arch Osteoporos. 2015;10(1):1-7. 
11. De Souza MT, Silva MD, Carvalho R. Revisão integrativa: o que é e como fazer. Einstein [Internet]. 2010 [acesso em 29 dez. 2017];8(1):102-6. Disponível em: http://www.scielo.br/scielo.php?script $=$ sci_ arttext\&pid=S1679-45082010000100102\&lng=pt\&nr $\mathrm{m}=$ iso\&tlng $=\mathrm{pt}$

12. Dal Sasso MK, Silveira RC, Galvão CM. Revisão integrativa: método de pesquisa para a incorporação de evidências na saúde e na enfermagem. Texto \& Contexto Enferm [Internet]. 2008 [acesso em 29 dez. 2017];17(4):758-64. Disponível em: http://www. scielo.br/scielo.php?script $=$ sci_arttext\&pid $=\mathrm{S} 01040$ 7072008000400018\&lng=en

13. Copês RM, Dal Osto LC, Langer FW, Vieira AR, Da Silveira Codevilla AA, Sartori GR, et al. Low health related quality of life associated with fractures in obese postmenopausal women in Santa Maria, Brazil. Bone Rep [Internet]. 2017 [acesso em 12 fev. 2017];(6):70-3. Disponível em: https://www.sciencedirect.com/science/article/pii/ S2352187217300086?via\%3Dihub
14. Langer FW, Da Silveira Codevilla AA, Bringhenti R, Dal Osto LC, Campos TR, Martins TT, et al. Low self-awareness of osteoporosis and fracture risk among postmenopausal women Arch Osteoporos. 2016;27(11):1-6.

15. Premaor MO, Pilbrow L, Tonkin C, Parker RA, Compston J. Obesity and fractures in postmenopausal women. J Bone Miner Res. 2010;25(2):292-97.

16. Kanis JA, Oden A, Johansson H, McCloskey E. Pitfalls in the external validation of FRAX. Osteoporos Int. 2012;23(2):423-31.

17. De Lima KC, Veras RP, Caldas CP, Da Motta LB, Bonfada D, Santos MM, et al. Effectiveness of intervention programs in primary care for the robust elderly. Salud Pública Méx [Internet]. 2015;57(3):26574. Disponível em: http://www.redalyc.org/articulo. oa?id=10638801010

18. Pinheiro MM, Eis SR. Epidemiology of osteoporotic fractures in Brazil: what we have and what we need. Arq Bras Endocrinol Metab [Internet]. 2010 [acesso em 29 dec. 2017];54(2):64-70. Disponível em: http:// www.scielo.br/scielo.php?script=sci_arttext\&pid=S0 00427302010000200012\&lng=en 